\title{
DiseasePlan - a spreadsheet application for training people to assess disease severity and to assist with standard area diagram development
}

\author{
Marcos Robson Sachet ${ }^{1 *}$ Idemir Citadin $^{1}$ Moeses Andrigo Danner ${ }^{1}$ \\ Marieli Teresinha Guerrezi ${ }^{2}$ Rafael Henrique Pertille ${ }^{2}$
}

'Programa de Pós-graduação em Agronomia, Departamento de Agronomia, Universidade Tecnológica Federal do Paraná (UTFPR), Via do Conhecimento, km 1, 85503-390, Pato Branco, PR, Brasil. E-mail: marcos.sachet@ufrr.br. "Corresponding author.

${ }^{2}$ Graduação em Agronomia, Departamento de Agronomia, Universidade Tecnológica Federal do Paraná (UTFPR), Pato Branco, PR, Brasil.

\begin{abstract}
Several computer applications have been proposed for the visual assessment of plant disease severity; however, they have some restrictions such as not permitting the user to make modifications. Therefore, the VBA-Excel application was developed as a means to train people to estimate disease severity and to validate standard area diagrams through images and disease severity values (percentage, rating or score) inserted into a database. The main performance statistics are screen displayed and spreadsheet recorded. Finally, the authors hope to receive evaluations and feedback regarding this application.

Keywords: phytopathological studies, pathometry, visual assessment.
\end{abstract}

DiseasePlan - Aplicativo de planilha para treinamento de avaliadores de doença e para auxiliar o desenvolvimento de escalas diagramáticas

RESUMO: Vários aplicativos de computador têm sido propostos para a avaliação visual da severidade de doenças em plantas, no entanto, estes possuem restrições como não permitir modificação pelo usuário. Por isso, desenvolvemos uma aplicação em VBA-Excel que permite o treinamento de avaliadores e validação de escalas diagramáticas através de imagens e severidade da doença (percentagem, nota ou escore) inseridos em um banco de dados. As principais estatísticas de desempenho são apresentadas e gravadas em planilha eletrônica. Finalmente, os autores esperam contar com a avaliação e a crítica referente a este aplicativo.

Palavras-chave: estudos fitopatológicos, patometria, avaliação visual.

There are multiple ways to quantify the response of a host to a pathogen, but the most commonly used is the visual assessment of lesions on a particular organ. A standard area diagram set (SAD) and specific training software can improve visual evaluations, allowing better results and reliable conclusions regarding the pathosystem to be attained.

For SAD development and validation, images of host organs (fruits, leaves, stems or trunks, and roots) are assessed with known disease severity, with and without the help of diagrams. In general, digital images are shown to the rater through imaging software, in which: there is no randomization of the images; no record of estimates; and no calculation of the accuracy, precision or other statistical parameters of quality assessment.

Several phytopathometric computer applications have been proposed: Distrain (TOMERLIN \& HOWELL, 1988); Disease.Pro
(NUTTER \& WORAWITLIKIT, 1989); Barley.Pro, Alfalfa.Pro, Corn.Pro, Grape.Pro, Soybean.Pro and Severity.Pro, SiTAV, ST-Aval, QuantiPest/DidactePIC, Phomadidacte, WinCombro and Soy Disease Analyzer. The main restrictions of these software packages are that they need to remain connected to the internet, program needs to be installed, or they are not free to access. Further to this, it is not always that the application can be modified by the user. Thus, the development of a spreadsheet application that allows the training of people to assess disease severity and $\mathrm{SAD}$ validation through their own data sets, while overcoming these restrictions is of great benefit.

The Disease Plan Application was developed using Visual Basic for Applications in Microsoft Office Excel (MS-Excel). Although a commercial license for MS-Excel is needed, it is the main spreadsheet editor used by the academic and scientific community. Applications made through macros and userform 
do not require installation, only a copy of MS-Excel 2007 or higher with the macro option enabled. The application can automatically adjust to the MS-Excel language (English or Portuguese).

How to use DiseasePlan: First step, the user needs to create a pathosystem folder, which needs to contain a JPEG image set and a file with the associated severity values called 'severity.txt' (Figure 1). For disease severity approximations several possible software programs can be used, i.e., image processing by ImageJ, AFSoft or Hypercube, as was used by NICOLI et al. (2015), or replicas of lesions need to be drawn on transparent plastic and read by an area meter as used by CITADIN et al. (2008).

Second step, 'DiseasePlan.xlsm' is the executable file, it must be saved, together with the other files, in the pathosystem folder. When it is run, a startup screen is shown where the user selects the pathosystem. After selection, an assessment screen appears, this contains randomized non repeating images, and fields to insert data: user identification, actual and predicated severity, number of decimals for the estimates and statistics. There is also the option to hide or demonstrate actual severity and statistics that are useful for the SAD validation (Figure 2).

Third step, the data are saved inside the 'Rater' spreadsheet, the main statistics used in the phytopathometric assessments are: linear equation and p-value for the coefficient and intercept; absolute deviation (predicted minus actual severity); and concordance correlation (CCC), precision and accuracy coefficients according to LIN (1989, 2000). From these data the rater performance may be evaluated. Furthermore, the database generated allows other inferences, such as the calculation of the assessment rate (i.e., assessments per minute), progress over time, or serial dependence tests.

In conclusion, DiseasePlan is able to assist in the training of people to assess disease severity and SAD development. The current version includes four pathosystem folders: bacterial spot (Xanthomonas arboricola pv. pruni) on peach leaves and fruits (Prunus persica); peacock eye (Fusicladium oleagineum) on olive leaves (Olea europaea); and anthracnose (Colletotrichum gloeosporioides) on feijoa fruits (Acca sellowiana). Pathosystem folders

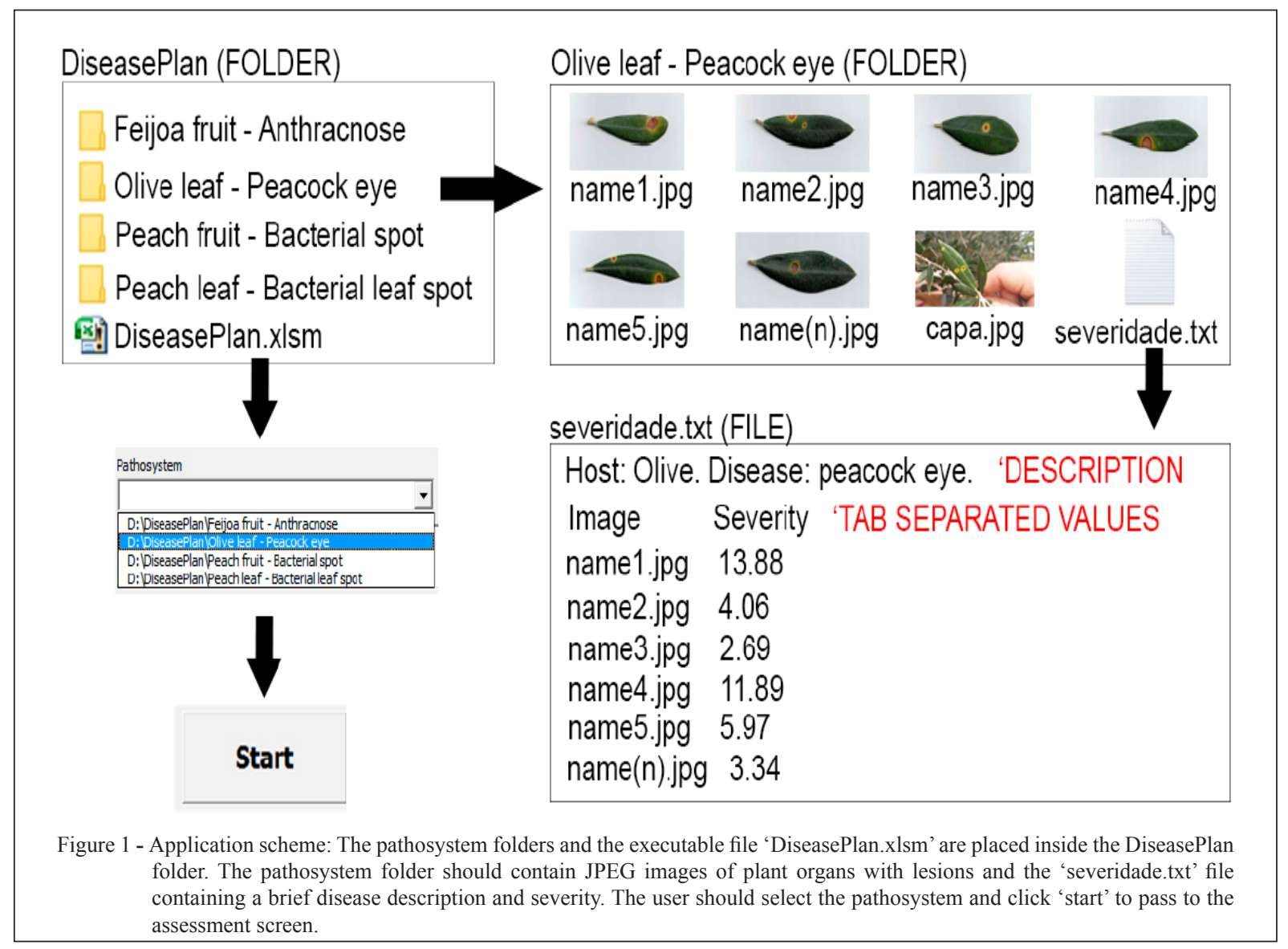

Ciência Rural, v.47, n.6, 2017. 


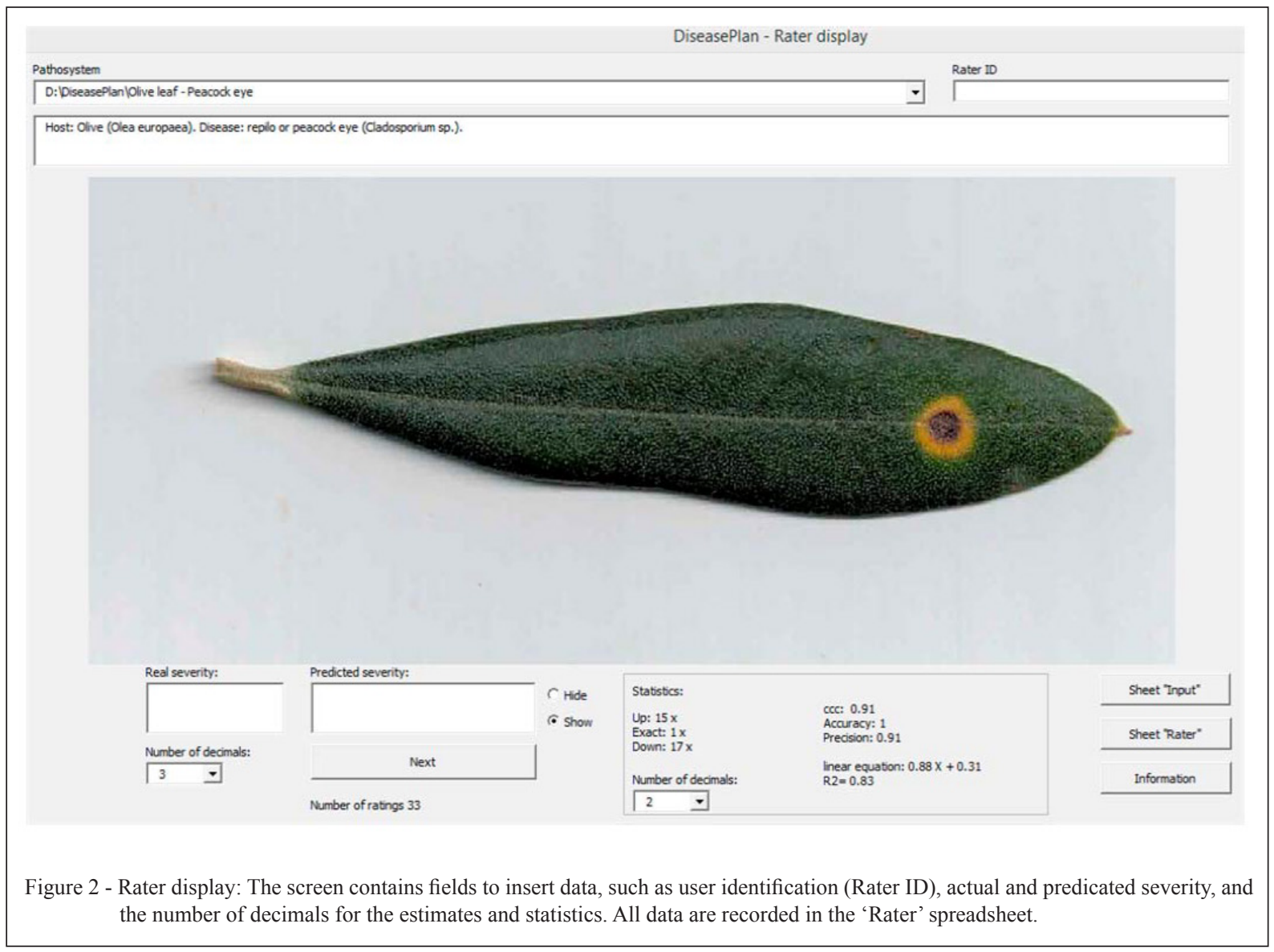

can be shared among research groups in order to standardize assessments among raters, locations or seasons. The VBA code is open access, editable and shareable, it can be downloaded from $<\mathrm{https} / / /$ dx.doi.org/10.13140/RG.2.2.28963.66088 $>$ or can be requested directly from the first or second author.

\section{REFERENCES}

CITADIN, I. et al. Diagramatic scale to evaluate the severity of bacteriose in peach trees. Revista Brasileira de Fruticultura, v.30, p.327-330, 2008. Available from: $<$ http://www.scielo.br/scielo.php?script=sci arttext\&pid $=$ S0100-29452008000200010>. Accessed: Oct. 07, 2016. doi: $10.1590 / \mathrm{S} 0100-29452008000200010$.

LIN, L.I. A concordance correlation coefficient to evaluate reproducibility. Biometrics, v.45, p.255-268, 1989. Available from: <https://www.jstor.org/stable/2532051>. Accessed: Oct. 07, 2016. doi: $10.2307 / 2532051$.

LIN, L.I. Correction: a note on the concordance correlation coefficient. Biometrics, v.56, p.324-325, 2000. Available from: $<$ http://www.jstor.org/stable/2677159>. Accessed: Oct. 07, 2016.

NICOLI, A. et al. Diagrammatic scale validation to quantify the severity of anthracnose stalk in corn. Ciência Rural, v.45, p.1720-1726, 2015. Available from: <http://www.scielo.br/scielo. php? script $=$ sci arttext\&pid $=$ S0103-84782015001001720 $>$. Accessed: Oct. $0 \overline{7}, 2016$. doi: 10.1590/0103-8478cr20141510.

NUTTER JR, F.W.; WORAWITLIKIT, O. Disease.Pro: a computer program for evaluating and improving a person ability to assess disease proportion. Phytopathology, v.79, p.1135, 1989

TOMERLIN, J.R.; HOWELL, T.A. Distrain: a computer program for training people to estimate disease severity on cereal leaves. Plant Disease, v.72, p.455-459, 1988. 